\title{
A SAPPHIRINE-ORTHOPYROXENE-SPINEL OCCURRENCE IN THE PIÊN AREA, PARANÁ, SOUTHERN BRAZIL
}

\author{
VICENTE A.V. GIRARDI* and H.H.G.J. ULBRICH*
}

\begin{abstract}
A minor outcrop of a sapphirine-bearing rock within migmatites is geologically associated with the large mafic-ultramafic complex at Piên, State of Paraná, S. Brazil. The rock, petrographycally classified as a sapphirine meta-norite, is characterized by a fine-grained equilibrium mosaic texture, with plagioclase (An 60\%), bronzite, sapphirine and green spinel as main minerals. The sapphirine is observed as symplectitic intergrowths with orthopyroxene and as isolated grains associated with plagioclase and orthopyroxene. Accessory minerals, not associated texturally with sapphirine crystallization, are garnet and some retrograde minerals. Chemically, the rock presents high $\mathrm{Al}_{2} \mathrm{O}_{3}$ and $\mathrm{MgO}$ contents and low $\mathrm{SiO}_{2}$ ratios. with a strongly undersaturated normative mineralogy. It is suggested that the original material was a spinel-rich ultramafic rock. The sapphirine probably crystallized by a combination of reactions involving mainly Al-pyroxenes, olivine and spinel. A 2-pyroxene geothermometer, applied to associated mafic and ultramafic rocks, indicates for the granulitic metamorphism a temperature of crystallization between 750 and $880^{\circ} \mathrm{C}$ and minimum pressures of $7 \mathrm{~Kb}$, while temperatures estimated from the $\mathrm{Al}$ content of orthopyroxenes coexisting with sapphirine are much too high. Similar conclusions are drawn from the coexistence of sapphirine, bronzite and spinel, which suggests a crystallization temperature of about $800^{\circ} \mathrm{C}$ or more, at a minimum pressure of $4 \mathrm{~Kb}$.
\end{abstract}

RESUMO O presente trabalho descreve ocorrência de safirina na região de Piên, Paraná. A rocha portadora do mineral, petrograficamente classificada como safirina metanorito, caracteriza-se pela presença de bronzita, plagioclásio $\left(\mathrm{An}_{60}\right)$, safirina e espinélio como minerais principais. A safirina ocorre sob forma de intercrescimento simplectítico com ortopiroxênio e também em grãos isolados. Minerais acessórios, não associados texturalmente à cristalização da safirina, são granada e minerais retrógrados. Quimicamente, a rocha exibe alto conteúdo de $\mathrm{Al}_{2} \mathrm{O}_{3}$, baixo de $\mathrm{SiO}_{2}$ e caráter fortemente insaturado. Sugere-se que a rocha ígnea original, relacionada provavelmente ao processo de diferenciação magmática ocorrida na formação original do complexo máfico-ultramáfico, era uma ultramáfica, portadora de espinélio. Durante a recristalização granulítica, formaram-se safirina, provavelmente devido a combinação de reações envolvendo principalmente piroxênio aluminoso, olivina e espinélio. Geotermometria, baseada em piroxênios coexistentes, aplicada às rochas máficas e ultramáficas do complexo, indica que o metamorfismo granulítico ocorreu a temperaturas entre $750-880^{\circ} \mathrm{C}$ e pressões mínimas de $7 \mathrm{~Kb}$. Temperaturas estimadas através do conteúdo de $\mathrm{Al}_{2} \mathrm{O}_{3}$ dos ortopiroxênios coexistentes com safirina são muito altas.

INTRODUCTION Sapphirine is a relatively rare mineral in metamorphic parageneses. It is restricted to undersaturated rocks rich in $\mathrm{Al}_{2} \mathrm{O}_{3}$ and $\mathrm{MgO}$, mostly recrystallized under conditions of the granulite facies (e.g., Wilson and Hudson, 1967; Nixon et al., 1973). In Brazil, only one occurrence from Salvador, Bahia, was described up to now (Allard and Fujimori, 1966; Stormer, 1973; Stormer and Whitney, 1977).

* Instituto de Geociências da Universidade de São Paulo - C.P. 20.899, Cidade Universitária - São Paulo, SP 
This communication describes a new occurrence from the Piên area, Paraná (southern Brazil), where the sapphirine-bearing rock is found as a single isolated outcrop near a main road, about $1 \mathrm{~km}$. north of the city of Trigolândia (Fig. 1). Bulk and mineral chemistries are presented and the data used to evaluate approximate temperatures and pressures of equilibration.

GENERAL GEOLOGY The Piên area is characterized by the presence of a medium-sized mafic-ultramafic complex. The outcrops are very poor in the whole area, and are mostly restricted to a scattering of unconnected boulders. Whatever inferences can be drawn from detailed field work indicate that the ultramafic units are present as two independent lenticular bodies, separated by a centrally-located

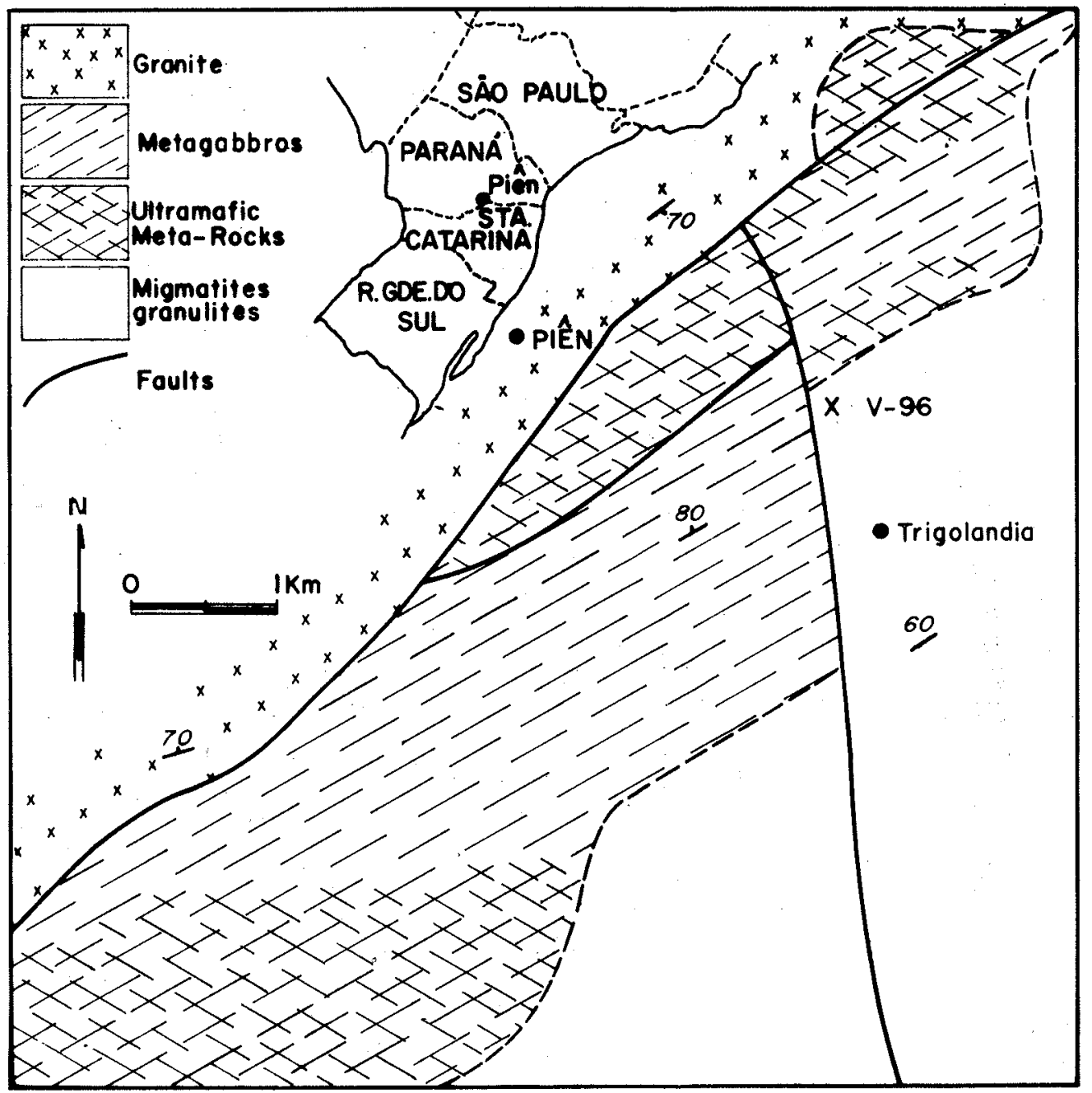

Figure 1 - Simplified map of a part of the Piên mafic-ultramafic complex (cf. Girardi, 1974). The sapphirine outcrop is identified by an $X$ (sample number is V-96). 
larger body of mafic rocks. The elongation of these bodies is roughly NE-SW, in general coincident with the strike of the foliation of country-rock migmatites. Dominant ultramafic rocks are serpentinites and magnesian schists, associated with lesser amounts of melanocratic meta-norites, meta-websterites and meta-olivine pyroxenites. The mafic rocks are predominantly meta-gabbros, with some lesser quantities of amphibolites and amphibole gneisses. Mineralogical studies indicate that these rocks recrystallized during an early granulitic metamorphism and were later overhauled by an amphibolite-facies metamorphism and by transformations at still lower temperatures (for details, see Girardi, 1976, and Girardi and Ulbrich, 1979). The migmatites are mostly of a granitic-granodioritic type, with biotite and amphiboles as important mafic minerals. Granulitic lenses within migmatites are commonly observed, although they are not very abundant. Most frequently, these granulites are of intermediate or basic composition; acid and ultrabasic granulites are very rare. Contacts of the mafic-ultramafic complex to the N, NE and W are mostly with the intrusive late-tectonic, post-migmatitic Agudos granite.

$\mathrm{Rb} / \mathrm{Sr}$ and $\mathrm{K} / \mathrm{Ar}$ geochronological work (Girardi et al., 1974) yields ages of recrystallization of about 2000 my (corresponding to events of the Transamazonic cycle), both for the mafic rocks of the Piên complex as well as for the intermediate and basic granulite lenses within migmatites. Thus ages as well as chemical similarities (see Girardi and Ulbrich, 1979) suggest a close genetic link between the maficultramafic complex and the granulitic lenses. The regional migmatites, on the other hand, are in part very old and as such probably also related to the Transamazonic cycle, but most of them are much younger and a product of the Brasiliano cycle of tectonic and metamorphic events (about $650 \mathrm{my}$. and younger). Geologic data are so far insufficient to outline the tectonic history of the area; the relationships between the Brasiliano migmatites and the older ones are still unknown, and little can be said about contacts between the granulitic lenses and their enclosing migmatites, on the one hand, and between the mafic and ultramafic units of the complex, on the other. But chemical data and radiometric ages (see also Girardi and Ulbrich, 1979) indicate a complex evolution, which can be summarized as follows. After the emplacement of the mafic-ultramafic complex (probably as a deformed or faulted magma chamber, initially subjected to mechanisms of gravity differentation, cf. Girardi and Ulbrich, 1979), a Transamazonic metamorphism re-equilibrated the rocks under granulite-facies conditions. The granulitic lenses within migmatites were probably offshoots of the mafic-ultramafic complex. The area was affected again during the Brasiliano cycle, now under an amphibolitefacies regime characterized by water inflow and regional migmatization. A last event is the low-temperature (Brasiliano-related ?) transformation which converted ultramafites into serpentinites and magnesian schists.

MINERALOGY AND PETROGRAPHY The sapphirine-bearing rock is here described as a melanocratic sapphirine meta-norite, and is devoid of clinopyroxene (Table I). The outcrop is a meter-sized boulder found in an area of migmatites; nothing could however be ascertained about field relationships with the enclosing rocks. Dominant minerals are orthopyroxene (bronzite) and labradorite (Án 60 ), with spinel and sapphirine as important subordinate phases; garnet is present only in veins and thus texturally unconnected to the sapphirine paragenesis. Retrograde minerals, mainly after orthopyroxenes, are talc, greenish-colorless am- 
phibole and chlorite. The rock is texturally a fine-grained inequigranular mosaic, and shows visible signs of shearing and microfaulting, as made apparent by the subparallel alignment of thin veinlets with alteration minerals (talc and chlorite). Olive-green spinel appears as small irregular grains. Orthopyroxene shows a large gradation in size, from large and rare $\mathrm{mm}$-sized crystals to small interstitial grains. Sapphirine is present as granules and in symplectitic intergrowth with orthopyroxene (photomicrograph 1). Granular sapphirine is the predominant variety; it is observed mostly as irregular crystals of varying sizes, and may in some cases be connected to fingers of the symplectitic variety. The sapphirine-orthopyroxene intergrowths are made up usually by about $2 / 3$ of orthopyroxene as host crystal. The symplectitic sapphirine, mostly in optical continuity, is observed as parallel or radiating narrow fingers within the pyroxene and as irregular myrmekite-like intergrowths; more rarely, it appears as "droplets" within the pyroxene host. The rock is strongly subsaturated, with high $\mathrm{Al}_{2} \mathrm{O}_{3}$ and moderate $\mathrm{MgO}$ contents; consequently, about half of its norm is taken up by ol and $c$ (Table I).

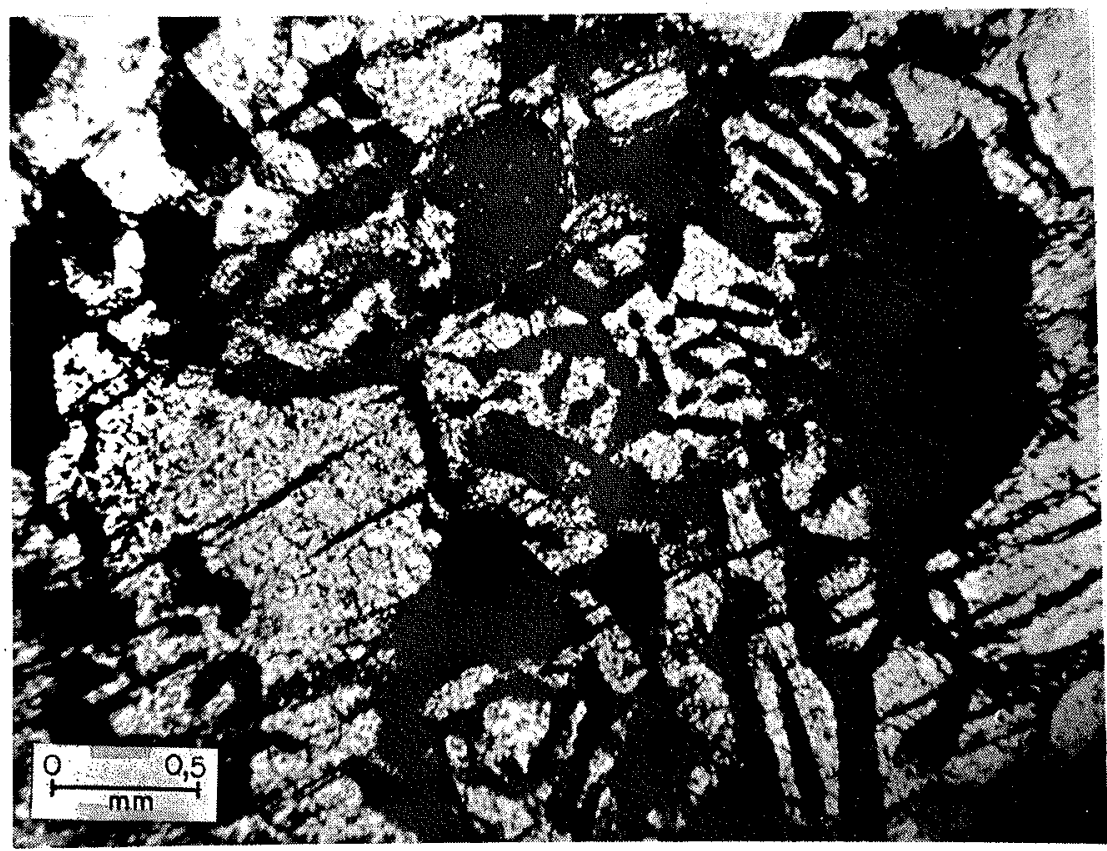

Photomicrograph 1 - In black, sapphirine in symplectitic intergrowth and as granules; bronzite is light-grey and shows good cleavage (crossed nichols).

Sapphirine, bronzite and garnet were analyzed with the microprobe (for instrumental details, see Girardi, 1974) and the results are given in Table II.

Sapphirine. There is no chemical or optical difference between the symplectitic or granular variety. The pleochroic scheme is $X$ : pale yellowish to pale greyish; $Y$ : greenish blue; $Z$ : conspicuous greenish blue; the dispersion is strong with $r<v$. The simplest sapphirine formula is $\mathrm{Mg}_{2} \mathrm{Al}_{4} \mathrm{SiO}_{10}$ (e.g. Ackermand et al., 1975) and this requires a minimum of $2 \mathrm{Al}$ in tetrahedral positions. Usually, there is a certain 
Table I - Data on sapphirine meta-norite

\begin{tabular}{|c|c|c|c|c|c|c|c|}
\hline Mode & & & Chemicd & anc & (ppm) & & Norm \\
\hline Orthopyroxene & 58.0 & $\mathrm{SiO}_{2}$ & 41.30 & $\mathrm{Cr}$ & 2000 & Or & 1.18 \\
\hline Plagioclase & 16.4 & $\begin{array}{l}\mathrm{TiO}_{2}^{2} \\
\mathrm{Al}_{2} \mathrm{O}_{3}\end{array}$ & $\begin{array}{r}0.23 \\
19.20\end{array}$ & $\mathrm{Ni}$ & 460 & $\mathrm{Ab}$ & 20.31 \\
\hline Sapphirine & 10.3 & $\mathrm{Fe}_{2} \mathrm{O}_{3}$ & 2.60 & Co & 100 & An & 16.87 \\
\hline Spinel & 5.0 & $\begin{array}{l}\mathrm{FeO} \\
\mathrm{MnO}\end{array}$ & $\begin{array}{l}9.26 \\
0.29\end{array}$ & Sc & 28 & $\mathrm{C}$ & 8.85 \\
\hline Garnet & 2.0 & $\mathrm{MgO}$ & $\begin{array}{r}19.65 \\
3.40\end{array}$ & $\mathrm{Zr}$ & 120 & Hy & 4.34 \\
\hline Talc & 4.0 & $\mathrm{CaO}$ & $\begin{array}{l}3.40 \\
0.90\end{array}$ & $\mathrm{Cu}$ & 10 & $\mathrm{Ol}$ & 42.78 \\
\hline $\begin{array}{l}\text { Amphibole } \\
\text { Chlorite }\end{array}$ & $\begin{array}{l}2.5 \\
1.8\end{array}$ & $\begin{array}{l}\mathrm{Na}_{2} \mathrm{O} \\
\mathrm{H}_{2} \mathrm{O}^{+}\end{array}$ & $\begin{array}{l}2.40 \\
1.50\end{array}$ & $\begin{array}{l}\mathrm{V} \\
\mathrm{Sr}\end{array}$ & $\begin{array}{l}48 \\
26\end{array}$ & $\begin{array}{l}\text { Il } \\
\text { Mt }\end{array}$ & $\begin{array}{l}0.44 \\
3.77\end{array}$ \\
\hline
\end{tabular}

Si deficiency in natural sapphirines, so that additional $\mathrm{Al}$ has to be added to tetrahedral positions (e.g., Deer et al., 1963; Stormer, 1973). Charge-balance thus requires that some of the iron presented conventionally in Table II as $\mathrm{Fe}^{2+}$ has to be converted into $\mathrm{Fe}^{3+}$; consequently, a small excess of octahedral cations (on a basis of oxygen $=10$ ) has to be expected in most analyses of natural sapphirines. Table II compares the chemical formulae of the Piên and the Salvador sapphirines which are on the whole very much alike.

Table II - Chemical analyses of sapphirine, orthopyroxene and garnet

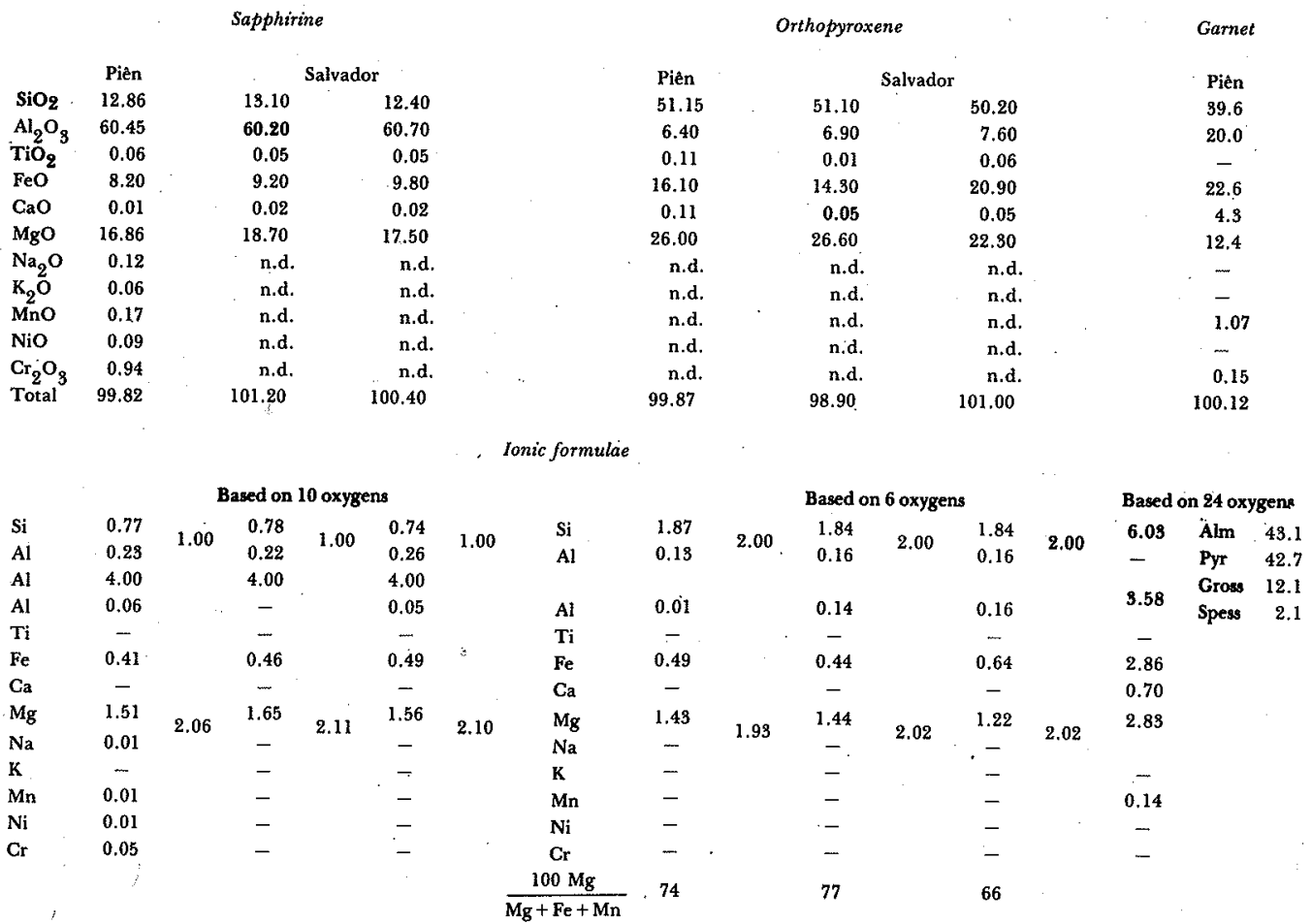


Orthopyroxene. It is an Al-rich unzoned bronzite, very similar in composition to one of the orthopyroxenes reported from the Salvador occurrence by Stormer (1973; see also Table II).

Garnet. Although texturally not related to the other minerals, since it appears within veinlets, its composition is nevertheless compatible with the garnet chemistry found in granulitic terrains (Table II; cf. discussion in Girardi, 1974).

CHEMICAL REACTIONS LEADING TO SAPPHIRINE FORMATION There is little geological information, especially about the source rock, to be gained from outcrops at the Piên site. Inferences have thus to be drawn from textural or chemical criteria. In particular, the symplectitic sapphirine-orthopyroxene intergrowth is conspicuous and suggests that such a texture was produced by a breakdown reaction of preexisting $\mathrm{Al}$-rich phases. A list of possible reactions in: volving sapphirine (obtained from a listing of the REACTION program by Finger and Burt, 1972) shows only one possible candidate to explain intergrowths, namely, the recrystallization of spinel with an Al-rich high-temperature orthopyroxene to produce sapphirine and an Al-poorer orthopyroxene:

$1 \mathrm{Mg}$-tschermakite (Mg-Ts, Opx) +1 Spinel = 1 sapphirine

where $(\mathrm{Mg}$ - $\mathrm{Ts}, \mathrm{Opx})$ stands for the $\mathrm{Mg}$-tschermakite component in orthopiroxene. Granular sapphirine in this paragenesis, on the other hand, may be formed by several possible reactions, a few of which are listed:

$2 \mathrm{Mg}$-Tschermakite $(\mathrm{Mg}$-Ts, Opx $)+1$ Forsterite $=1$ sapphirine +1 enstatite (2)

$1 \mathrm{Mg}$-tschermakite (Mg-Ts, Opx) + 1 Forsterite $=2$ sapphirine +1 Enstatite (3)

1 Ca-Tschermakite (Ca-Ts, Cpx) $+2 \mathrm{Mg}$-Tschermakite $(\mathrm{Mg}-\mathrm{Ts}, \mathrm{Opx})=1 \mathrm{Sap}-$

phirine +1 Anorthite

In reaction (4), (Ca-Ts, Cpx) stands for the Ca-Tschermakite component in a preexisting clinopyroxene.

There are very few rocks that can qualify chemically as source material for sapphirine-bearing assemblages. One possible source, fitting the chemistry of the Piên rock, is a plagioclase-bearing, orthopyroxene-rich spinel olivine-pyroxenite (see Winkler, 1976, p. 159). Another possible source are the thin blackwall zones of metasomatic origin, rich in chlorites or chlorites and amphiboles (cf. Evans, 1977, p. 437 , and references therein). But it is difficult to explain a symplectitic intergrowth solely on the basis of breakdown reactions of hydrated blackwall minerals. This would indicate that the source for the Piên rock was a high-grade assemblage, either a preexisting ultramafic material or a blackwall already converted by a previous metamorphism into a dehydrated granulite with $\mathrm{Al}$-rich pyroxenes, spinels, etc. Acceptance of the last hypothesis would mean that former blackwalls were converted into high-grade granulites prior to the sapphirine formation. $\mathrm{Ob}$ viously, the least complicated alternative is thus to assume that the source rock although poor outcrops leave the question open - was a spinel-bearing ultramafite or a very melanocratic spinel norite, originally present as a tectonically transported fragment or as an ultramafic vein or dikelet. This occurrence may therefore be related to the rare ultramafic granulite lenses found within migmatites, which are here associated with the ultramafic rocks of the Piên complex (Girardi and Ulbrich, 1979). 
GEOTHERMOMETRIC AND GEOBAROMETRIC ESTIMATES An interpretation of the chemical composition of coexisting minerals in the Piên massif in the light of recently proposed geothermometers suggests for the Transamazonic granulitic recrystallization a temperature interval from about $750^{\circ} \mathrm{C}$ to about $880^{\circ} \mathrm{C}$ (cf. details in Girardi and Ulbrich, 1979). The most consistent geothermometers for ultramafic and mafic rocks are apparently those comparing compositions of coexisting pyroxenes, as initially proposed by Wood and Banno (1973) and later modified by Wells (1977). Temperatures found according to Well's scheme of calculation range from about $880^{\circ} \mathrm{C}$ to about $730^{\circ} \mathrm{C}$ for the ultramafic Piên rocks, while temperatures from basic granulite lenses within migmatites cluster closely around $750^{\circ} \mathrm{C}$. A geothermometer by Banno (1974) corroborates these temperature estimates, yielding figures that are within the estimated error interval for pyroxene tinermometry. A calibration of the spinel-olivine thermometer by Evans and Frost (1975) suggests maximum temperatures of about $800^{\circ} \mathrm{C}$ for some Piên ultramafites. A geobarometric method developed by O'Hara (1967) shows a crystallization temperature of about $1050^{\circ} \mathrm{C}$ and a corresponding pressure of about $5 \mathrm{~Kb}$, for one meta-olivine pyroxenite, but these results have to be taken with caution, since O'Hara's grid is based on incomplete data. On the other hand, the proposal by Obata (1976; cf. also Evans, 1977, p. 412) allows geobarometric estimates as a function of temperature of formation and the $\mathrm{Mg}$-tschermakite content in orthopyroxenes; the use of Obata's grid for the Piên ultramafites yields approximate pressures ranging from about 5 to $7 \mathrm{Kbs}$. However, the presence of some garnet, especially in a few Piên meta-gabbros, suggests that the pressures of the Transamazonic crystallization were probably somewhat higher (cf. discussion in Girardi and Ulbrich, 1979).

Nevertheless, as has been discussed elsewhere (e.g., Stormer and Whitney, 1977), figures based on today's two-pyroxene thermometry probably exaggerate the actual crystallization temperatures by as much as $100^{\circ} \mathrm{C}$. Thus, it is likely that the granulitic crystallization of the Piên mafic and ultramafic rocks took place at pressures above $7 \mathrm{~Kb}$. and at peak metamorphic temperatures probably not higher than about $800^{\circ} \mathrm{C}$, if the possible temperature exaggeration introduced by the pyroxene thermometer is considered.

The coexistence of granular sapphirine, spinel and $\mathrm{Mg}$-rich orthopyroxene, in addition to the data on orthopyroxene chemistry presented in Table II, allows further estimates on temperatures and pressures of crystallization. Sapphirine formation has been investigated especially by Seifert $(1974,1975)$ and Ackermand et al. (1975). Experimental work by these authors in the iron-free $\mathrm{MgO}-\mathrm{Al}_{2} \mathrm{O}_{3}-\mathrm{SiO}_{2}-\mathrm{H}_{2} \mathrm{O}$ system defines a large stability field for $\mathrm{Mg}$-sapphirine (Fig. 2). The coexistence of spinel, granular sapphirine and orthopyroxene, however, is only possible in a restricted region of the phase diagram, as shown by the phase triangles $A$ and $B$ in Fig. 2. Of the two, triangle $B$ is the only one applicable to the present case, since phase triangle A shows chlorite as a stable high-temperature mineral (in the Piên rock, chlorite is retrograde). It is observed that minimum temperatures of crystallization for the phase assemblage of triangle $B$ in the iron-free system are $800^{\circ} \mathrm{C}$ or over. The minimum pressure to stabilize such an association is close to $4 \mathrm{~Kb}$. $\mathrm{Ob}$ viously, iron in the formulae of the reacting minerals stabilizes them at lower temperatures than the ones shown in Fig. 2, but preliminary information shows that the lowering in stability fields may not go beyond a few tens of degrees, if at all; in 


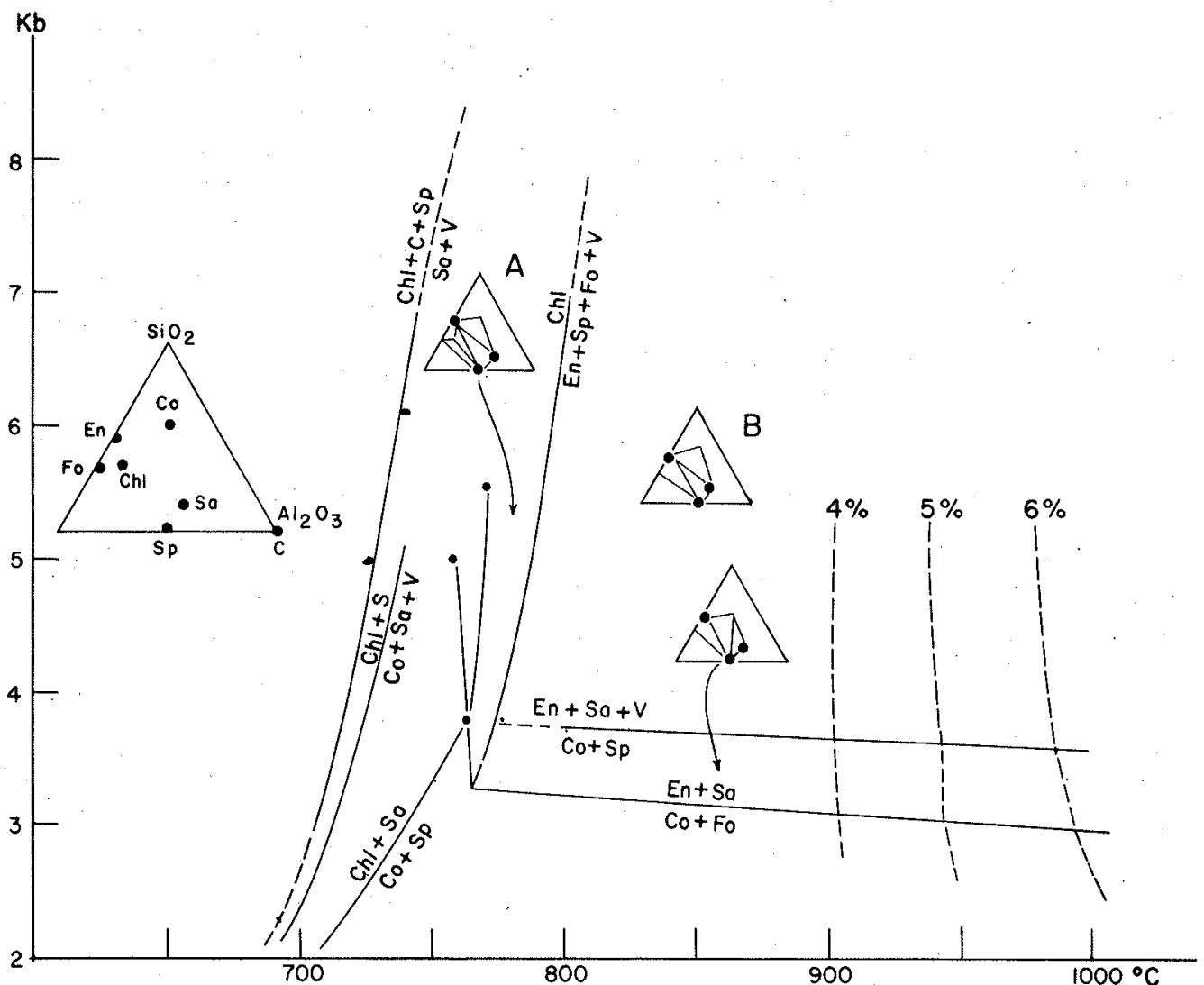

Figure 2 - Reactions in the alumina-rich part of the $\mathrm{Al}_{2} \mathrm{O}_{3} \cdot \mathrm{MgO}-\mathrm{SiO}_{2}-\mathrm{H}_{2} \mathrm{O}$ system (see text for explanations). Large dots in phase triangles identify enstatite, sapphirine and spinel. Note that coexistence of sapphirine, spinel and enstatite is only possible for the phase regions in the diagram identified by phase triangles $\mathbf{A}$ and B. Dashed lines represent approximate $\mathrm{Al}_{2} \mathrm{O}_{3}$ content (in weight percent) of orthoenstatites in sapphirine-bearing assemblages (drwan from data by Anastasiou and Seifert, 1972). C: corundum; Chl: Mg-chlorite; Co: $\mathrm{Mg}$-cordierite; En: enstatite; Fo: forsterite; Sa: sapphirine; $\mathrm{Sp}$ : spinel; V: vapor.

addition, the Fe content of most minerals is almost pressure-insensitive (cf. discussion about the role of Fe in Stormer and Whitney, 1977). The information obtained from Seifert's phase diagram thus shows that the Piên sapphirine crystallized under pressure and temperature conditions that on the whole are compatible with results obtained from pyroxene composition in other Piên rocks. It also suggests that sapphirine formation is the product of the same metamorphism that reequilibrated the rocks of the Piên massif.

The $\mathrm{Al}_{2} \mathrm{O}_{3}$ content of orthopyroxenes has been investigated by several authors (e:g., McGregor, 1975; Anastasiou and Seifert, 1972). McGregor's data, according to many authors (e.g., Obata, 1976; Sinton, 1977) should be discarded and will not be applied here. The results shown by Anastasiou and Seifert (1972) on $\mathrm{Al}_{2} \mathrm{O}_{3}$ solubility in orthoenstatite in sapphirine- and spinel-bearing systems are drawn into Fig. 2. It is apparent that $\mathrm{Al}_{2} \mathrm{O}_{3}$ content is very pressure-insensitive, ex- 
cept at high temperatures $\left(1100^{\circ} \mathrm{C}\right.$ and over). The Piên orthopyroxene presents close to $7 \% \mathrm{Al}_{2} \mathrm{O}_{3}$ (Table II), so that a temperature estimate based on the data by Anastasiou and Seifert would imply crystallization of the Piên pyroxene at $1000^{\circ} \mathrm{C}$ or more. All other temperature estimates are against such a conclusion, and doubt has to be cast, if not necessarily on the results shown by Anastasiou and Seifert, at least on the possibility of applying their $\mathrm{Al}_{2} \mathrm{O}_{3}$ solubility diagram to natural systems.

Acknowledgments The authors thank the Brazilian National Research Foundation (CNPq) for financial support and an unknown referee for this constructive criticism of an earlier version.

\section{REFERENCES}

ACKERMAND, D., SEIFERT, F., and SCHREYER, W. - 1975 - Instability of sapphirine at high pressures. Contr. Mineral. Petrol., 50: 79.92

ALLARD, G.O. and FUJIMORI, K. - 1966 - A new occurrence of sapphirine in Salvador, Bahia, Brazil. Canad. Mineral. 8: 660

ANASTASIOU, P. and SEIFERT, F. - 1972 - Solid solubility of $\mathrm{Al}_{2} \mathrm{O}_{8}$ in enstatite at high temperature and $1-5 \mathrm{~Kb}$ water pressure. Contr. Mineral. Petrol., 34: 227-281

BANNO, S. - 1974 - Use of partial solution of multi-component equilibria. Case study on pyroxene-bearing assemblages. Bull. Soc. fr. Mineral. Cristall., 97: 108-116

DEER, W.A., HOWIE, R.A. and ZUSSMAN, J. - 1963 - Rock-forming minerals. Longmans, London

EVANS, B.W. - 1977 - Metamorphism of alpine peridotite and serpentinite. Ann. Rev. Earth Planet. Sci., 5: 397-447.

EVANS, B.W. and FROST, B.R. - 1975 - Chrome-spinel in progressive metamorphism: a preliminary analysis. Geoch. Cosmoch. Acta, 39: 259-272

FINGER, L.W. and BURT, D.M. - 1972 - Reaction, a Fortran-IV Computer Program to balance chemical reactions. Ann. Rep. Director Geoph. Lab., Year book, 71: 616610

GIRARDI, V.A.V. - 1974 - Petrologia do Complexo Básico-Ultrabásico de Piên, PR. Unptublished Livre Docência Thesis. Univ. São Paulo, USP

GIRARDI, V.A.V. - 1976 - Geologia e Petrologia do Complexo Básico-Ultrabásico de Piên, PR. Rev. Bras. Geoc., 6: 109-124

GIRARDI, V.A.V., CORDANI, U.G., CANDIDO, A., MELFI, A.J. e KAWASHITA, K. - 1974 - Geocronologia do Complexo Básico-Ultrabásico de Piên, PR. Anais XXVIII Congr. Bras. Geol., 6: 245-252

GIRARDI, V.A.V. and ULBRICH, H. - 1979 - Origin and evolution of the Piên mafic-ultramafic complex, southern Brazil, submitted to J. Geol.

MAC GREGOR, I.D. 1975 - Solubility of $\mathrm{Al}_{2} \mathrm{O}_{3}$ in enstatites for spinel and garnet peridotite compositions. Am. Mineral, 59: 110-119

NIXON, P.H., REEDMAN, A.J. and BURNS, L.K. - 1973 - Sapphirine-bearing granulites from Labwor, Uganda. Min. Mag., 39: 420-428

OBATA, M. - 1976 - The solubility of $\mathrm{Al}_{2} \mathrm{O}_{3}$ in spinel and plagioclase peridotites and spinel pyroxenite. Am. Miner. 61: 804-816

O'HARA - 1967 - Mineral paragenesis in ultrabasic rocks, in Wyllie, P.J., ed., Ultramafic and related rocks, Wiley, New York, 393-403

SEIFERT, F. - 1974 - Stability of sapphirine: a study of the aluminous part of the system $\mathrm{MgO}-\mathrm{Al}_{2} \mathrm{O}_{3}-\mathrm{SiO}_{2}-\mathrm{H}_{2} \mathrm{O}$. J. Geol. 82: 173-204 
SEIFERT, F. - 1975 - Boron-free kornerupine: a high-pressure phase. Am. J. Sci. 275: 57.87

SINTON, J.M. - 1977 - Equilibration history of the basal alpinetype peridotite. Red Mountain, New Zealand, J. Petrol., 18: 216-246

STORMER Jr., J.C. - 1973 - The composition of sapphirine from Salvador, Bahia, and conditions of its formation. Rev. Bras. Geoc., 3, (3): 192-200

STORMER Jr., J.C., and WHITNEY, J.A. - 1977 - Two-feldspar geothermometry in granulite facies metamorphic rocks. Contrib. Mineral. Petrol, 65: 123-133

WELLS, P.R.A. - 1977 - Pyroxene thermometry in simple and complex systems. Contr. Mineral. Petrol. 53: 71-104.

WILSON, A.F. and HUDSON, D.R. - 1967 - The discovery of beryllium-bearing sapphirine in the granulites of the Musgrave ranges (Central Australia). Chem. Geol. 2: $209-215$

WINKLER, H.G.F. - 1976 - Petrogenesis of metamorphic rocks, 4th. edition, Springer, New York, $334 \mathrm{p}$.

WOOD, B.J. and BANNO, S. - 1973 - Garnet-orthopyroxene and orthopyroxene-clinopyroxene relationships in simple and complex systems. Contr. Mineral. Petrol., 42: $109-124$ 